\title{
Health as a Value in the Integration Policy of European and East Asian Countries. Historical and Legal Perspective ${ }^{1}$
}

\author{
Robert TABASZEWSKI
}

\section{Introductory notes}

Concern about health has been present since the onset of existence of human communities: European and Asian. Philosophic and legal rules requiring to respect human health can already be found in the works of ancient scholars on both continents. ${ }^{2}$ According to Plato, health is the first and foremost personal interest and the highest value of human life, followed by beauty and wealth respectively. ${ }^{3}$ It was likewise defined by Plutarch, who emphasized the significance of work, freedom and activity as determinants of health in his work De tuenda sanitate praecepta. ${ }^{4}$ On the other hand, the foundations of the European view on health are based on the subjective concepts of Hippocrates. ${ }^{5}$

Cooperation in the field of health also constituted grounds for the initiation of cooperation among European states, being the prototype of the present-day legal community. Signs of concern about health are still visible on the European continent. Johan P. Mackenbach clarified:

"conversely, travellers to historical places in Europe will have no difficulty in identifying remnants of public health as it was in the past: think of Roman aqueducts and baths, medieval hospitals, pictures and monuments testifying to the terror of the Black Death, working and housing conditions before the twentieth century, et cetera". ${ }^{6}$

Ancient Rome was famous not only for concern about personal hygiene, leaving behind cultural monuments in the form of thermae and sewers, but also the obligation to respect human health was written in the law. ${ }^{7}$ Concern about the health of the entire population, combating epidemics and promoting a healthy lifestyle was a part of the

1. This work was supported by the National Science Centre, Poland under project No. reg. 2017/01/X/ HS5/00840.

2. D. PORTER, Health, Civilisation and the State. A history of public health from ancient to modern times, Routledge, London, 1999, pp.11-23.

3. N. RIEGEL, Goodness and beauty in Plato, in: Archai, 12(2014), pp.147-158.

4. A. JORI, Medical popularization and moral therapy in Plutarch's Treatise de tuenda sanitate praecepta (Ygieina paraggelmata), in: Medicina nei Secoli, 3(2007), pp.667-703.

5. L.S. KING, Hippocrates and Philosophy, in: Journal of the History of Medicine and Allied Sciences, 1(1963), pp.77-78.

6. J.P. MACKENBACH, The History of public health in Europe, in: European Journal of Public Health, 6(1996), p.79.

7. N. MORLEY, The Salubriousness of the Roman City, in: H. KING (ed.), Health in Antiquity, Routledge, London, 2005, pp.192-204. 
foreign policy of the Roman Empire. In its administrative structure, there was even a special section of adjutant imperial physicians. In the Middle Ages, concern about health was a feature of the development of trade between Europe and Asia and epidemic hazards connected with it. ${ }^{8}$ Concern about health was also present among Asian communities, in particular under the influence of Confucius's philosophy ${ }^{9}$

\section{Health as common value in the policy of European countries until the first half of the 20th century}

From the perspective of the history of European integration, protection of health, both in common and individual aspects, took a new meaning in the period of the so-called geographic "discoveries". In respect of the creation of the concept of a modern state, it was considered that the affluence and development potentialities of countries are associated with the health of the people inhabiting the countries..$^{10}$ However, in the period of the Ancien Régime, there was a dominating conviction that the health of the subjects does not constitute value to themselves, but rather to the whole country, and it was the monarch who eventually decided on the life and health of the subjects. In the 17th century, the administrative tasks of European countries were caring for the total population potential of epidemics. ${ }^{11}$

Only in the second half of the $18^{\text {th }}$ century, under the influence of the philosophic ideas of the Enlightenment, the thesis that not only the individual should provide resources intended for protection of health, but this should also be the responsibility of the state and administration, was more widely accepted in Europe. The period of 80 years between 1750 and 1830 was of key importance. George Rosen explained:

"the peculiar interest of these decades derives from the creation during this period of the foundation for the sanitary movement of the nineteenth century, a development fraught with the momentous consequences for modern public health". ${ }^{12}$

A change of the paradigm with regard to health occurred as late as during the French Revolution. ${ }^{13}$ As a result of a breakthrough in exact sciences, the principle of stateorientation was gradually replaced by the principle of equality in hospitals. Ministries

8. D. PORTER, op.cit., pp.24-45.

9. See: L. MENG-KIN, Values and Health Care: The Confucian Dimension in Health Care Reform, in: The Journal of Medicine and Philosophy: A Forum for Bioethics and Philosophy of Medicine, 6(2012), pp.545-555.

10. H.K. Abrams, A short history of occupational health, in: Journal Public Health Policy, 1(2001), pp. 34-80.

11. See: C.E. ROSENBERG, Explaining Epidemics: and Other Studies in the History of Medicine, Cambridge University Press, Cambridge, 1992, p.54-57.

12. G. ROSEN, A history of public health, Johns Hopkins University Press, Balitmore, 1996, p.79.

13. See: M. PELLING, M. HARRISON, P.WEINDLING, The industrial revolution, in: C. WEBSTER (ed.), Caring for Health: History and Diversity, The Open University Press, Ballmoor, 2001, pp. 61-96. 
of health and medical schools emerged, scientific cooperation in the field of medicine developed among countries on the basis of relevant provisions contained in the rules of conduct. While in the Declaration of the Rights of the Man and of the Citizen, there was no reference to the health of the individual, in 1791, as a result of the activity of the "Comité de salubrité de l'Assemblée nationale constituante" health was considered as one of the policies of the state and a commitment of the authorities towards the individual. ${ }^{14}$ Therefore, in the period of 1793-94, a law introducing public healthcare was passed in France. Earlier, first voluntary social insurance policies were introduced in Denmark in 1790, and then in other European countries. ${ }^{15}$

In the middle of the 19th century, following diplomatic cooperation among European states, conferences which topic was legal cooperation in sanitary issues were initiated. The first such conference, convened in Paris in 1851, was attended by 12 representatives of European states. The purpose of this conference was to prepare an international sanitary conference obliging the states to adopt minimum requirements within the scope of marine quarantine and against the spread of cholera. The consecutive Sanitary Conferences, of a clearly sectorial nature, were held in Paris in 1859, in Constantinople in 1866, in Vienna in 1874, in Washington in 1881, in Rome in 1885, in Venice in 1892, in Dresden in 1893, in Paris in 1894 and in Venice in 1897. ${ }^{16}$ Norman Howard-Jones clarified:

"the discussions at these international confrontations vividly reflect medical thinking as it really was, and provide a salutary corrective to the foreshortened and romanticized accounts of individual discoveries that often pass for medical history". ${ }^{17}$

The full institutionalisation of the cooperation among European states began only in 1903, when the International Sanitary Convention was ratified in Paris, which obliged the states to implement counter epidemic instruments. The supervision over the execution of the convention was to be exercised by a special health bureau with its seat in Paris. In executing the resolutions contained in Article 181 of this convention, on 9 December 1907, within the framework of the International Sanitary Conference in Rome, the International Office of Public Hygiene (OIHP) was founded. ${ }^{18}$

The outbreak and course of World War I substantially influenced the legal regulations adopted in the field of individual and common health. The foundation of the League of Nations, the first international organisation of universal character, allowed for establishing grounds for organised cooperation in the field of health among Euro-

14. Assemblée nationale constituante, Comité de salubrité, Paris, 1789-1791.

15. See: A. TOS, R. TABASZEWSKI, Denmark in European Union - Danish Attitudes towards European Cooperation, in: H. CHALUPCZAK, J. MISIAGIEWICZ, P. TOSIEK (eds), European integration: models, challenges, perspectives, Monografie i Opracowania, Zamosc, 2012, pp. 121-132.

16. V. HUBER, The unification of globe disease?, in: The Historical Journal, 2(2006), pp.453-476.

17. N. HOWARD-JONES, The scientific background of the International Sanitary Conferences 18511938, WHO, Geneva, 1975, p.9.

18. M.A. OSBORNE, The Several Meanings of Global Health History: The Case of Yellow Fever, Rockefeller Archive Center Research Reports, Oregon, 2017, pp.55-14. 
pean and Asian countries. ${ }^{19}$ In accordance with Article 23 of the Covenant of the League of Nations, the countries "will endeavour to take steps in matters of international concern for the prevention and control of disease". Whereas, in light of Article 25 of the Covenant of the League of Nations, reflecting humanitarian concern about the human being, it was stated that

"the Members of the League agree to encourage and promote the establishment and cooperation of duly authorised voluntary national Red Cross organisations having as purposes the improvement of health, the prevention of disease and the mitigation of suffering throughout the world".

To achieve the above purpose on both continents, the Health Organization was founded in Geneva in 1920, which dealt with the standardisation and control of the trade in medicine, preparation of the classification of diseases and even setting an optimal and individual diet and examining the condition of food and nutrition in Europe, Asia and other parts of the world. ${ }^{20}$ The activities of health organisations were hindered by the World War II, the atrocities of which forced more intensive cooperation among countries in the area of health.

\section{Health as a constituent of the integration policy of the European Communities}

Respect for human health, understood as the duty of public authorities, was evinced by the European Communities from the beginning of their establishment, but the respect was not comprehensive. Meri Koivusalo emphasizes

"the relationship between health and European policies long remained nominal. Clearly, it can be assumed that the founding fathers in Rome or later in Maastricht would not have assumed that health services would become part of the broader agenda". ${ }^{21}$

This approach resulted from the view that the competences of the newly founded WHO in 1946 should not be doubled. ${ }^{22}$ It differed from the complementary Asian approach in this respect, as Asians recognised the competences of the WHO within the scope of the naming and classification of diseases, but they did not abstain from their national medical practices.

Numerous references to health were included in the founding treaties as a result of the common stance of the Ministers of Health of Belgium, the Netherlands and Luxembourg. The premise for protection of health was indirectly included in the

19. J.W. FISCHER, The Covenant of the League of Nations and War, in: The Cambridge Law Journal, 1(1933), pp.1-21.

20. The Health Organization of the League of Nations, in: The British Medical Journal, 2(1927), p. 1157.

21. M. KOIVUSALO, European Health Policy and Practice, in: S. SANKARI (ed.), The Many Constitutions of Europe, Routledge, London, 2016, p.236.

22. J. CHARLES, Origins, history, and achievements of the World Health Organization, in: The British Medical Journal, 2(1968), pp.293-296. 
Treaty of Paris of 1951 as well as directly in the Treaties of Rome of 1957. One of the purposes of the EEC was "an improvement in working and living conditions", while one of the purposes of the European Atomic Energy Community (EAEC) was the intention to create the conditions of safety necessary to "eliminate hazards to the life and health of the public", and Chapter 3 was entitled "Health and Safety". Dorte Sindbjerg Martinsen clarified:

"A European health community was launched as a political idea in the formative years of European integration. Already back in 1952, the French Minister of Health, Paul Ribeyre presented a detailed idea, with 330 articles of supranational healthcare regulation. The idea of a European health community was, however, refused by the EEC's founding fathers. Health regulation was to be a national prerogative". ${ }^{23}$

Therefore, individual health was on the edge of the community policies for years. It only changed in 1967 when individual consultative committees on protection of health were set up within the framework of the Community. In the 1970s two committees were established: the Standing Committee on Safety in Mining and Industry and the Consultative Committee on Safety, Hygiene and Health Protection at Work. ${ }^{24}$ Separate consultative committees for the training of medical staff: physicians, nurses and pharmacists were also created. As it can be seen, the activities of the committees, initially focused on the issues of the freedom of movement of patients and medical staff, were later targeted at other aspects of life, including the quality and trade control of medical, pharmaceutical products, tobacco, alcohol, diet and nutrition, and environmental determinants. ${ }^{25}$

It can be said that the new common approach to health, as the interest of the entire Community and not of individual European countries only, was taken in 1986, when in light of the Single European Act, the states were obliged to ensure its citizens a high level of health protection, and particular care was given to specific categories of persons: workers and consumers. ${ }^{26}$ In this respect, protection of health was treated as the duty of every European state, obliged to create such conditions for their citizens which would allow the citizens to sufficiently maintain their health status non-deteriorated. Among other things, the guarantees concerning the free movement of work-

23. D.S. MARTINSEN, Governing EU health law and policy - on governance and legislative politics, in: T.K. HERVEY, C.A. YOUNG, L.E. BISHOP (eds), Research Handbook on EU Health Law and Policy, Edward Elgar, Cheltenham-Northampton, 2017, p.36.

24. F.B. WRIGHT, Occupational health and safety: The European Union, in: J.M. STELLMAN (ed.), Encyclopedia of Occupational Health and Safety: The body, health care, International Labour Office, Geneva, 1998, pp.2331-2332.

25. S.L. GREER et al., EU action for health, in: S.L. GREER et al.(eds) Everything you always wanted to know about European Union health policies but were afraid to ask, World Health Organization, London, 2014, pp.37-38.

26. Single European Act, signed at Luxembourg on 17 February 1986, entered into force on 1 November 1993. 
ers, goods and services, including those related to health and medicine, were to serve the above purpose. ${ }^{27}$

At the end of the 1980 's, health began to be widely regarded as a human right. Standards concerning protection of health at work were included in the Charter of Fundamental Social Rights for Workers signed by the European Council in 1989.28 During the works on the Treaty on European Union, it was considered that there was an urgent need to impose further duties on the Member States in respect of promotion of public health. As early as in 1991, at a special meeting of the Council and Ministers of Health of 12 countries on 11 November, the principle of state responsibility for the organisation of healthcare systems and public health security was introduced in the resolution then passed. ${ }^{29}$ Nonetheless, in subsequent resolutions, the Ministers agreed that cross-border global problems could not be solved by traditional methods without cooperation with Eastern Europe and Asian countries. Adoption of joint actions with countries from outside the Community was to facilitate prevention of diseases, especially large epidemics, combating drug addiction, enable support of research on infectious diseases and on how they are transmitted, and also allow for exchange of information and knowledge with regard to health matters.

Medical cooperation of the Member States with Asian countries was facilitated by the adoption of the Maastricht Treaty; ${ }^{30}$ Article 129 thereof was particularly useful. The most important provision however was the one stipulating that protection of health constitutes an integral part of all Community policies, and at the same time it was stated that the Community and the Member States should support cooperation with third countries and relevant international organisations in protection of health. ${ }^{31}$ Soon after, the European Commission released a "Communication on the scope of works in the area of public health" containing references to the following fields of cooperation in protection of health: research into the causes of mortality and morbidity, cooperation in major health and demographic trends, development of healthcare systems, development of new technologies as well as increase in social expectations for healthcare. The Treaty also included a rule which obliged the Member States to coordinate policies and programmes relating to health among themselves and with the Commission. That meant that the Commission, being in close contact with the Member States, could also undertake on its own any initiatives useful for cooperation with countries and organisations from outside the EU.

27. T.K. HERVEY, The right to health in EU law, in: T.K. HERVEY, J. KENNER, Economic and Social Rights Under the EU Charter of Fundamental Rights: A Legal Perspective, Hart Publishing, Oxford-Portland-Oregon, 2003, p.203.

28. The Community Charter of the Fundamental Social Rights of Workers, signed in Strasbourg on 9 December 1989.

29. R. ABBING, Health Law \& the European Union, in: European Journal of Health Law, 1(1994), pp.123-126.

30. The Treaty on European Union, signed at Maastricht on 7 February 1992, entered into force on 1 November 1993.

31. R. ABBING, Public health in the Treaty of Amsterdam, in: European Journal of Health Law, 2(1998), p.173. 
Another breakthrough in understanding health as a personal right which should be cared about not only by the state but also by the individual came with the solutions adopted in the Treaty of Amsterdam. The resolutions contained therein were directly influenced by the BSE epidemic which showed the helplessness of European and state sanitary authorities in the field of health security. ${ }^{32}$ Thus, the multi-element definition of health was taken over from the WHO, which was reflected in Article 159 and Article 152 of the Treaty which states that

"Community action, which shall complement national policies, shall be directed towards improving public health, preventing human illness and diseases, and obviating sources of danger to human health". ${ }^{33}$

The responsibility for protection of human health was put on the Member States. In the light of Article 152(5) of the Treaty, the Member States were held fully responsible for the organisation, financing and delivery of health services and medical care. ${ }^{34}$ The Treaty also created an opportunity to promote mutual cooperation in combating epidemics and cross-border health problems. In 2002, the first Programme of Community action in the field of public health for the years 2003-2008 was adopted in which it was aptly recognised that health is a priority human right.

A clear division of competences between the EU and the Member States in the field of maintaining the health of individuals was introduced by the Treaty of Lisbon. ${ }^{35}$ A general cooperation commitment is imposed in Article 168 of the TFEU which states that the EU should ensure a high level of human health protection in all its policies and actions and complement endeavours of the Member States. The term "health" appears in the Treaty of Lisbon 26 times in various contexts. In the light of the Treaty, health policy is currently an independent EU policy, and each action of the EU which complements national policies must be directed towards improving public health, including preventing physical and mental illness and diseases, and obviating sources of danger to physical and mental health. Note that the said regulations are further specified in the EU strategies and programmes of action in the field of health. As emphasized by Advocate General Niilo Jääskinen, protection of health is necessary to guarantee fundamental rights, human dignity, the right to life and the right to physical and mental integrity guaranteed in the Charter of Fundamental Rights. ${ }^{36}$

32. The Treaty of Amsterdam amending the Treaty on European Union, the Treaties establishing the European Communities and certain related acts, signed in Amsterdam on 2 October 1997, entered into force on 1 May 1999.

33. M. HILF, E. PACHE, Der Vertrag von Amsterdam, in: Neue Juristische Wochenschrift, 705(1998), pp.705-713.

34. S. CUCIC, European Union health policy and its implications for national convergence, in: International Journal for Quality in Health Care, 3(2000), pp.217-225.

35. M. GUY, W. SAUTER, The History and Scope of EU Health Law and Policy, in: CCP Working Paper, 2(2018), p.24.

36. Opinion of Mr Advocate General Jääskinen delivered on 10.07.2014, ECLI:EU:C:2014:2072. 


\section{Health as a field of cooperation between the EU and ASEAN}

Currently, the perception of health protection in Asia is slightly different than it is in Europe. While in the EU particular existential rights are exercised under the principles of liberalism and individualism, in Asia, as Francis Fukuyama indicates, the respect for health and well-being is conditioned on a long-established tradition and the nature of Confucian values. ${ }^{37}$ Admittedly human rights are of a universal character, but in practice, the Asian context, which encompasses specific thinking, attitudes and behaviour, should also be taken into account. Since the second half of the $20^{\text {th }}$ century, health has been properly appreciated by Asian countries as part of human social rights. In particular from the perspective of the ASEAN countries, health is a part of the UN Millennium Development Goals (MDGs) and the Sustainable Development Goals (SDGs) as an indispensable component of respect for human rights.

Human right to health and human right to healthcare are the leading rules of public international law. ${ }^{38}$ However, the concept of human rights and freedoms is understood slightly differently on the European continent than in particular Asian countries. The possibilities and measures of human rights protection are different in terms of quality in both systems. In Europe, after 1948, the concept of human rights has been developed by the following international organisations: the Council of Europe (since 1949), the EU (since 1993) and the Organization for Security and Co-operation in Europe (since 1995). Contrary to residents of East Asia countries, citizens of EU states have the capacity to protect their rights, including the possibility to lodge a complaint with European courts. On the other hand, the protection of the human right to health in the EU is not of an absolute nature. Hence, due to an increasing terrorist threat, the EU and its individual member states have competences to restrict individual freedoms, taking into consideration public interest and safety. ${ }^{39}$

The specificity of the Asian approach to human rights stems from the fact that as opposed to Europe, Asian values are not based on liberalism and individualism, but on community ties and respect for work, discipline and education..$^{40}$ Thus, ever since the adoption of the "Charter of the United Nations" in 1945, and then the passing of the "Universal Declaration of Human Rights" in 1948, the concept of "human rights" developed by the United States in these documents has been treated in China and some other Asian countries as an attempt to Westernise the East. ${ }^{41}$ During the cultural

37. F. FUKUYAMA, Confucianism and democracy, in: Journal of Democracy, 2(1995), pp.20-33.

38. R. TABASZEWSKI, Human rights and freedoms in systems of human rights protection, in: K. KOZIOL (ed.), The Limits to Human Freedom, Regis, Lublin 2017, pp.10-31.

39. N. MAIER-KNAPP, The EU and non-traditional security in Southeast Asia, in: D. NOVOTNY, C. PORTELA (ed.), EU-ASEAN Relations in the 21st Century: Strategic Partnership in the Making, Palgrave Macmillan, London, 2012, pp.26-42; AFET, ASEAN: Integration, Internal Dynamics and External Relations, EU, Brussels, 9(2012), pp.6-8.

40. A. SEN, Human Rights and Asian Values, Carnegie Council on Ethics and International Affairs, New York, 1997, pp.13-16.

41. UN Charter and Statute of the International Court of Justice, signed on 26 June 1945 at the San Francisco Conference; Universal Declaration of Human Rights, Paris, December 10, 1948, G.A. res. 217A (III), U.N. Doc. A/810 at 71. 
revolution of 1966-1969, Mao Zedong strongly objected to this Westernisation attempt, saying that "the East wind must prevail over the West wind" ${ }^{42}$ This view was not isolated. As late as in the 1990s, the Prime Minister of Singapore Lee Kuan Yew had the opinion that "a well-organised society is more important than human rights, so that anyone can enjoy their freedoms". ${ }^{43}$ That is why Asian countries are by far more effective in ensuring safety of all their citizens than in implementing the "fundamental rights", as in the EU. ${ }^{44}$

There are also some differences in the approach to the universality of human rights between the European and Asian concepts. ${ }^{45}$ In the 1990s, the issues of respect for human rights were discussed by Asian countries at a debate which took place in Bangkok from 29 March to 2 April 1993.46 In light of Article 8 of the Bangkok Declaration, 34 Asian countries stated that

"human rights are universal in nature, they must be considered in the context of a dynamic and evolving process of international norm-setting, bearing in mind the significance of national and regional particularities and various historical, cultural and religious backgrounds". ${ }^{47}$

The text of the Declaration contained numerous references to Asian values as common for the societies of the region. It acknowledged that the promotion of human rights should be made through cooperation and consensus, and not through confrontation and dictating contradictory values. Appreciation and taking advantage of the wealth of all cultures may serve to enrich the human rights concept. This was later popularised by the Prime Minister of Singapore, Lee Kuan Yew. ${ }^{48}$ Even though the Declaration was not legally binding, the values mentioned in it were accepted not only by Asian countries. Those values were also included by the EU in the Common Foreign and Security Policy.

Another document where Asian values were named expressis verbis is the ASEAN Human Rights Declaration of 18 November 2012. In accordance with this document,

42. A. HALIMARSKI, Trzy kregi polityki zagranicznej Chin, KiW, Warsaw, 1982, pp.78 and 213.

43. F. ZAKARIA, L. KUAN YEW, Culture Is Destiny: A Conversation with Lee Kuan Yew, in: Foreign Affairs, 2(1994), pp.109-126; G. WANG, Lee Kuan Yew Through the Eyes of Chinese Scholars, S. Rajaratnam School of International Studies, Singapore, 2017, pp.139-143.

44. M. LEIFER, S. DJIWANDONO, Europe and Southeast Asia, in: H. MAULL, G. SEGAL, J. WANANDI (eds), Europe and the Asia Pacific, Routledge, London, 1998, p.203.

45. See: G. WIESSALA, Catalysts and Inhibitors - The Role and Meaning of Human Rights in EUAsia Relations, CERC Working Papers Series, Carlton, 1(2007); E. FITRIANI, The Impact of the EU Crisis On EU-ASEAN Relations, in: Geopolitics, History, and International Relations, 1(2014), p.82.

46. Y. GHAI, Human Rights and Governance: The Asia Debate, in: Asia Pacific Journal on Human Rights and the Law, 1(2000), pp.9-52.

47. Final Declaration of the Regional Meeting for Asia of the World Conference on Human Rights adopted on 2 April 1993, Bangkok, Singapore.

48. A. FOLLESDAL, Human Rights and Relativism, in: A. FOLLESDAL, T. POGGE, Real World Justice: Grounds, Principles, Human Rights, and Social Institution, Springer, Dordrecht, 2005, pp. 265-283. 
Asian values were considered as a prerequisite for enabling ASEAN member states to modify human rights for bio-political reasons ${ }^{49}$ In light of the Declaration

"the enjoyment of human rights and fundamental freedoms must be balanced with the performance of corresponding duties as every person has responsibilities to all other individuals, the community and the society where one lives. It is ultimately the primary responsibility of all ASEAN Member States to promote and protect all human rights and fundamental freedoms".

Thus, the Declaration stated that human rights alone are not of absolute character, and their enjoyment must be deliberated in national and regional contexts, taking into account political, economic, legal, social, cultural, historical, and religious conditions. ${ }^{50}$ Therefore, in light of the Declaration, it is possible to restrict existential rights, including the right of unlimited drug use, alcohol consumption, smoking and access to narcotic drugs, which affect the health condition of the whole populations, both European and Asian.

\section{Institutional and legal basis of bio-political cooperation between the $\mathrm{EU}$ and ASEAN}

While post-1945 European governments adapted existing infrastructures for improving access to primary health care, the idea of the protecting individual and community health in Asia was disseminated by the "World Health Organization" and its local branches in East Asia ("SEARO") only in the 1980s. ${ }^{51}$ According to the Preamble to the WHO Constitution of 1948, health is a state of complete physical, mental and social well-being and not merely the absence of disease or infirmity. Very similar definitions of health and bio-politics could be found in EU documents. Over the past two decades, this idea has been implemented in East Asia thanks to the efforts of the EU and its Member States. ${ }^{52}$

The main legal framework for relations with ASEAN, was the document called ASEAN-EEC Cooperation Agreement, signed in March 1980. The agreement is the cornerstone on which EC-ASEAN relations are based. ${ }^{53}$ The subsequent documents laying foundations for health cooperation were the New Partnership with Southeast

49. G.J. NALDI, K. MAGLIVERAS, The ASEAN Human Rights Declaration, in: International Human Rights Law Review, 3(2014), pp.183-208.

50. J. LING-CHIEN NEO, Religious Freedom and the ASEAN Human Rights Declaration: Prospects and Challenges, in: Review of Faith and International Affairs, 4(2016), pp.4-15.

51. R. CANAWAY, Integration of traditional and complementary medicine in South-East Asia: Public health, safety and management. A report for WHO-SEARO, WHO-SEARO, New Delhi, 2015.

52. The future of EU-ASEAN relations, European Parliament resolution of 15 January 2014 on the future of EU-ASEAN relations (2013/2148(INI)) (2016/C 482/11).

53. P. DE LOMBAERDE, G. PIETRANGELI, M. SCHULZ, The 'Makability' of Regions. Towards an Evaluation of EU Support to Regional Integration Worldwide, Conference on "The European Union in International Affairs"e, Brussels, 24-26.04.2008. 
Asia of July 2003 and the Nuremberg Declaration on an EU-ASEAN Enhanced Partnership of March 2007 and its Plan of Action of November 2007.54 These documents currently form the core of the dialogue between the EU and ASEAN. ${ }^{55}$ It was established that in an endeavour to realise human rights in East Asia, as well as in China and Japan, the EU should hold a common dialogue and take into consideration the local specificity of Asian values. ${ }^{56}$

The first areas where rapprochement between the EU and ASEAN occurred were the issues of safety and protection of public health, including combatting drug dealing. ${ }^{57}$ According to the Nuremburg Declaration, the EU was committed to support ASEAN in attaining "the Drug Free ASEAN 2015 goals" in identified areas through law enforcement cooperation and information dissemination. The EU was to encourage the development of regular dialogues and consultations, conduct personnel exchange programs, exchange information and promote activities and cooperation in priority fields to combat illegal drug trafficking and diversion of chemical precursors used in the manufacturing of illegal drugs. According to those documents, the EU focused on seminars on confidence-building measures and preventive diplomacy, including, inter alia, cooperation between ASEAN and European think-tanks. ${ }^{58}$

Actually, according to EU Guidelines on Foreign and Security Policy, East Asia is a region of dynamic health security change, in which the EU and its Member States have substantial interests. ${ }^{59}$ The rapid pace of economic change in East Asia has been directly reflected in patterns of health and disease in the region. The new model of EU health policies towards East Asia has been worked out in the "Third EU Health Programme 2014-2020". ${ }^{60}$ In the light of the above documents, the key element of the development of further European-Asian dialogue in the field of human rights is the issue of the protection of public health against the consequences of using drugs coming from South-East Asia. Asian countries have long been the focal point for drug smuggling to European markets. ${ }^{61}$ The production of opium and other narcotics in China, Japan and other Asian countries is concentrated in two main areas: the "Golden Crescent", which is formed by South-West Asian countries, and the "Golden Trian-

54. 2013/2148(INI).

55. A.C. ROBLES, An EU-ASEAN FTA: The EU's Failures as an International Actor, in: European Foreign Affairs Review, 4(2008), p.541.

56. See R. WONG, S. BROWN, Changing Waters: Towards a new EU Asia strategy. Stepping up EUASEAN Cooperation in Non-Traditional Security, The London School of Economics \& Political Science (LSE), London, 2016.

57. V. ROLLET, The EU as a health actor in Asia: EU-Asian interregional response to highly pathogenic and (re)-emerging diseases, in: H. SU (ed.), Asia's EU Policies, National Taiwan University Press, Taipei, 2015, pp.323-346.

58. Opinion of the European Economic and Social Committee on 'EU-ASEAN Relations', OJ C 21, 21.01.2011, p.21-25.

59. L. ALISON, The EU, ASEAN and Interregionalism: Regionalism Support and Norm Diffusion between the EU and ASEAN, Palgrave Macmillan UK, Robles 2008, p.190.

60. OJ L 86, Vol. 57, 21.03.2014.

61. L. GIOMMONI, How Do Illicit Drugs Move Across Countries? A Network Analysis of the Heroin Supply to Europe, in: Journal of drug issues, 2(2016), p.2. 
gle", which is composed of South-East Asian countries. ${ }^{62}$ While narcotics produced by way of chemical synthesis are produced in China, South Asian countries specialise in the production of and trade in traditional drugs.

According to WHO SEARO, illicit drug dealing should be combatted, even with the possibility of restricting human rights and freedoms. ${ }^{63}$ The EU is also interested in cooperation with ASEAN countries in fighting drug cultivation and smuggling. Narcotics travel to Europe via various smuggling channels from the East, South and West. The external Eastern border of the EU is the one that is endangered by these dealings the most. However, drug smuggling through state borders is currently hampered, especially as customs service agencies are equipped with better detecting devices. Whole smuggling networks are more frequently detected and eliminated. ${ }^{64} \mathrm{It}$ is also worth mentioning that the Asian countries are among those where penal measures are the strictest.

\section{Final remarks}

The health policies of the EU and ASEAN countries are gradually getting closer together. However, a lot needs to be done for mutual understanding of the traditional values on which both organisations are supported. Despite the closer EU-ASEAN cooperation within the scope of adopting further regulations concerning the protection of human health, illicit trade in harmful substances has not decreased. It must be combatted through joint implementation by public authorities of South-East Asian countries of plans and strategies for counteracting global threats, as well as establishing working parties within the framework of inter-parliamentary cooperation. It is necessary not only to fight poverty, which is conducive to drug production, on a global scale, but also to strengthen the cooperation of the agencies of EU member states with their counterparts in Asian countries. Only then, cooperation in the field of health will be fully effective.

62. A. TALPUR, T. GEORGE, A Review of Drug Policy in the Golden Crescent: Towards the Development of More Effective Solutions, in: Asian Journal of Psychiatry, 1(2014); S. AYESHA FAROOQ et al., Opium trade and the spread of HIV in the Golden Crescent, in: Harm Reduction Journal, 1(2017), pp.31-35.

63. See: P. NEWTON et al., The Primacy of Public Health Considerations in Defining Poor Quality Medicines, in: PLoS Medicine, 12(2012), p.4; D. MARES, Institutions, the Illegal Drug Trade, and Participant Strategies: What Corrupt or Pariah States Have In Common with Liberal Democracy and the Rule of Law, in: International Interactions, 35(2009), pp.207-239.

64. H.T. LUONG, Transnational Drugs Trafficking from West Africa to Southeast Asia: A Case Study of Vietnam, in: Journal of Law and Criminal Justice, 2(2015), pp.37-54. 